\title{
Improving Students' Achievement in Reading Descriptive Text through Reciprocal Teaching Strategy
}

\author{
Rohdearni Wati Sipayung \\ Teacher Training and Science Education Faculty (FKIP), Simalungun University, Indonesia \\ dearsipayunk@gmail.com
}

\begin{abstract}
This paper describes how to improve students' achievement in reading descriptive text through reciprocal teaching strategy. The sample of this paper are 21 Students of VIII-1 Grade in Senior High School of PTPN IV Bah Jambi. The pre-test data were distributed before the treatment of Reciprocal Teaching Strategy and the post-test data were taken after the treatment of teaching-learning reading descriptive text by using Reciprocal Teaching Strategy. The finding shows before the treatment of Reciprocal Reading Strategy, the basic knowledge of students at grade VIII SMP Swasta PTPN IV Bah Jambi was low since the mean of pre-test data was 25,95 and after the treatment, the students' achievement in reading descriptive text was good where the mean of post-test data was 69,76 so that the mean difference before and after the treatment was 43,81.
\end{abstract}

Keywords: students' achievement; reading, descriptive text; reciprocal teaching strategy

\section{Introduction}

Reading is about understanding written text. Reading is also the window of knowledge. By reading, people may get much information by understanding the content of the text and may know everything in the world. Vassiliou (2011:7), the written word is present everywhere and therefore reading is a fundamental skill which is increasingly needed in almost every sphere of life. A wide range of reading skills including digital reading are essential for an individual's personal and social fulfillment for taking an informed and active part in society and exercising full rights of citizenship.

Understanding a written text means extracting the required information from it as efficiently as possible. Reading is a constant process of guessing, and what one brings to the text is often more important than what one finds in it. This is why, from the very beginning the students should be taught to use what they know to understand unknown elements whether these are ideas or simple words so that teaching reading is very important for students. Vassiliou (2011:7), the successful acquisition of reading skills during childhood and adolescence is therefore fundamental. Furthermore, good literacy skills are the basis of a child's entire school career; without them academic success is unattainable. Students are expected to be able to get some knowladge and information from the text.

To do reading is not an easy activity for Indonesian students, of course because English is not their mother language. Indonesian language and English are difference; they are different in vocabulary, pronunciation, structure, and even in dialect. So, reading is very complex. As stated by Scanlon, et.al, (2010: $9 \&$ 346) reading is a complex process that requires the analysis, coordination, and interpretation of a variety of sources of information. Reading is also a complex process and children react to instruction in very different ways. Moreover, Pang, et.al (2003:21) also argued that teaching reading is difficult work. Teachers must be aware of the progress that students are making and adjust instruction to the changing abilities of students.

Those difficulties are also faced by students at grade VIII SMP Swasta PTPN IV Bah Jambi. From the writer's pre-observation and interview, students faced many difficulties when 
they read a text and those difficulties came from two different sides; they are from the students themselves and from the teachers' strategy. From the students, the students were unfamiliar with the words that are used in the text or lacking of vocabularies. The students did not have motivation to read because they assumed that the text was not interesting and was too long to read. Beside that they did not know about text structure which is used in the text and it appeared when they found preterit verbs and past participle verbs.

From the teacher, the writer found that the teacher is accustomed to use instructions in teaching students reading comprehension. It was starting from asking the students to read text by heart, finding difficult words, translating the text into Indonesia, and then asking the students to answer questions based on the text. The teacher did not pay attention on how to get information from the text by applying types of reading such as reading in the lines, between the lines, and among the lines, so that the students might get main ideas from each paragraph. The teacher was less attention on the structure used in the text and on how to pronounce the vocabularies. But, the teachers are supposed to be a professional person in the class. Those reading activities made students bored.

Referring to the problems of teaching reading activities above, the writer conducted a research of teaching reading comprehension by using Reciprocal teaching strategy and the writer believed that this teaching strategy would be capable of overcoming the students' difficulties in reading comprehension and as stated by Palincsar \& Brown, quoted by Carr, et.al (2004:196) reciprocal teaching strategy is a powerful teaching strategy consisting of a dialogue between a student leader and classmates as they read segments of a text together. In the dialogue, students use four separate strategies to increase their comprehension. The four strategies are summarizing, question generating, clarifying, and predicting, and they are used in that order. So, the writer then entitled this research title as: Improving Students' Achievement in Reading Descriptive Text through Reciprocal Teaching Strategy.

\section{Review Of Literature}

\subsection{Teaching Reading Comprehension}

How to teach reading skills to children whose mother language is not the language of instruction is, therefore, a crucial issue; such as Indonesian students. But, the important of English nowadays has forced Indonesian government to put English a compulsory lesson in curriculum started from playgroup level till university.

Teaching English covered teaching the four language skills; they are Listening, Speaking, Writing, and Reading. Reading is one language skills that should be mastered by students to become skillful person in the world because by reading, they can get more information from every side of the world. So, teachers should give their heart on how to improve students' achievement in reading comprehension and do not let the students just read the text as they know. As stated by Klingner, et.al (2007:6), knowing how to read, or decode, words is not a small part of the reading process; it is a critical link whose absence inhibits understanding. When students are beginning to read, they may have difficulty.

As students progress through reading, they may have difficulty reading, too. The goal is to identify, prior to reading, the key words that students are likely to have challenges decoding and teaching them so that students can read these words and use them in discussions and written expression. Teachers can provide support by teaching the decoding skills students need initially to read more basic words. After students can read basic words and have the 
fundamental phonics principles to decode words, then teachers need to provide instruction in the decoding of more complex and multisyllabic words.

According to Anderson, quoted in Nunan (2003:68), teaching reading usually has at least two aspects. First, it can refer to teaching learners who are learning to read for the very first time. A second aspect of teaching reading refers to teaching learners who already have reading skills in their first language. Pang, et.al (2003:21) stated that teaching reading is difficult work. Teachers must be aware of the progress that students are making and adjust instruction to the changing abilities of students. It is also important to remember that the goal of reading is to understand the texts and to be able to learn from them. So, in teaching reading comprehension to the students, teacher should also know the principles of teaching reading so that the teaching-learning process runs effectively and efficiently. Anderson, quoted in Nunan (2003:74) classified those principles as following:

\section{a. Exploit the reader's background knowledge}

Background knowledge includes all of the experiences that a reader brings to a text: life experiences, educational experiences, knowledge of how texts can be organized rhetorically, knowledge of how one's first language works, knowledge of how the second language works, and cultural background and knowledge so that the reading comprehension can be significantly enhanced if background knowledge can be activated by setting goals, asking questions, making predictions, teaching text structure (Carrell; Carrell and Connor, in Nunan 2003:74).

b. Build a strong vocabulary base

Role of vocabulary in reading instruction exists. So, basic vocabulary should be explicitly taught and second language readers should be taught to use context to effectively guess the meanings of less frequent vocabulary (Anderson in Nunan, 2003:74).

c. Teach for comprehension

Anderson, quoted in Nunan (2003:75) argued that monitoring comprehension is essential to successful reading. Part of that monitoring process includes verifying that the predictions being made are correct and checking that the reader is making the necessary adjustments when meaning is not obtained.

d. Work on increasing reading rate

Anderson, in Nunan (2003:76) explained that teacher must work towards finding a balance between assisting students to improve their reading rate and developing reading comprehension skills. It is very important to understand that the focus is not to develop speed readers, but fluent readers. One focus here is to teach readers to reduce their dependence on a dictionary. Skills such as scanning, skimming, predicting and identifying main ideas get students to approach reading in different ways.

\section{e. Teach reading strategies}

Anderson, quoted in Nunan (2003:76) defined that strategies are the tools for active, self-directed involvement that is necessary for developing communicative ability. To achieve the desired results, students need to learn how to use a range of reading strategies that match their purposes for reading. A good technique to sensitize students to the strategies they use is to get them to verbalize their thought processes as they read. 


\section{f. Encourage readers to transform strategies into skills}

Anderson, in Nunan (2003:77) argued that strategies can be defined as conscious actions that learners take to achieve desired goals or objectives, while a skill is a technique that has become automatic. This characterization underscores the active role that readers play in strategic reading. As learners consciously learn and practice specific reading strategies, the strategies move from conscious to unconscious; from technique to skill.

g. Build assessment and evaluation into our teaching

Anderson, quoted in Nunan (2003:77) argued that assessing growth and development in reading skills from both a formal and an informal perspective requires time and training. Both quantitative and qualitative assessment activities should be included in the reading classroom.

h. Strive for continuous improvement as a reading teacher

Nunan (2003:77) explained that reading teachers need to be passionate about their work. They should view themselves as facilitators, helping each reader discover what works best.

\subsection{Types of Reading}

There are many types of reading and some of them are described by Dakowska (2005:205-207), as following:

\section{a. Silent Reading}

It may be done in segments and mixed with more social, interactive forms of work with the text, helping the teacher to monitor the effects of silent reading.

\section{b. Reading Aloud}

Reading aloud by the language learner, on the other hand, provides the teacher with an insight into the way the learner segments the material into phrases and reconstructs the text structure.

\section{c. Extensive reading}

In extensive reading, the learner does not use external sources of information during this rather fluent process, but derives considerable orientation from the vast contexts with in by the passage. Extensive reading has the advantage of the quantity of input at the expense of the processing precision.

\section{d. Intensive reading}

It is connected with a more in-depth study and analysis of a relatively limited a mount of text as well as the use of external resources to supplement the learner's knowledge deficits. Intensive reading can lead to precision, but at the expense of the slower pace of the task.

\section{e. Skimming}

It is used to get a general idea of the nature of the text. For this purpose the reader makes use of important structural clues in the text, such as its appearance, the title, list of contents, abstracts, subtitles, topic sentences, illustrations, conclusions, where applicable.

\section{f. Scanning}

It involves searching rapidly through a text to find a specific point of information. Effectives canning is an important sub-ability in reading comprehension; it 
presupposes that we know where to look for the relevant information and thus strengthens our study skills.

\subsection{Reciprocal Strategy}

Reciprocal reading strategy is one of reading comprehension strategies that can improve the students' achievement in reading comprehension. As stated by Palincsar and Brown, quoted in Frank, et.al (2006:62), Reciprocal strategy is an interactive dialogue between the teacher and students regarding segments of text. The dialogue involves four strategies: predicting, question generating clarifying, and summarizing. Vassiliou (2011:37) argued that reciprocal teaching focused on where the teacher explains and demonstrates four comprehension strategies; question generation, summarization, clarification and prediction, and supports this through dialogue with the pupils as they attempt to gain meaning from text.

Besides that, Palincsar \& Brown, quoted in Carr, et.al. (2004:196) defined that reciprocal strategy is a powerful teaching strategy consisting of a dialogue between a student leader and classmates as they read segments of a text together. In dialogue, students use four separate strategies to increase their comprehension. The four strategies are summarizing, question generating, clarifying, and predicting, and they are used in that order. For Klingner, et.al (2007:131), reciprocal teaching was originally designed to improve comprehension for middle school students who could decode but had difficulty comprehending text.

Students learn to use the four strategies of prediction, summarization, question generation, and clarification and to apply these while discussing text with the teacher and their peers. The teacher first models how to implement the strategies. Next, through prompts, questions, and reminders, the teacher supports students' efforts to use the strategies while reading and discussing text. As students become more proficient, the teacher gradually reduces this assistance. The premise is that teaching students to use the four strategies collaboratively in a dialogue will help them bring meaning to the text as well as promote their internalization of the use of the strategies, thus ultimately improving their reading comprehension.

Based on quotations above it can be concluded that reciprocal strategy is a strategy that purposes of having students read carefully for understanding written text.

\section{a. Parts of Reciprocal Strategy}

Reciprocal reading comprehension strategy is conducted by four parts of strategies; summarizing, question generating, clarifying, and predicting (Carr, et.al, 2004:196).

\section{b. Summarizing}

Summarizing helps student synthesize information, determine the main idea and key details, and infer relationships among concepts (Carr, et.al, 2004:197).

\section{c. Question Generating}

Question generating helps students identify the key ideas in the text. As they develop questions, they solidify their understanding of the main points (Carr, et.al, 2004:197).

\section{d. Clarifying}

Clarifying is self-monitoring strategy that encourages students to restate what they have read to make sure it makes sense to them. If it does not, they stop and reread to figure out why it is not making sense. The process helps students identify text factors that impede their understanding, such as difficult concepts, new vocabulary, and unclear referents. With self- monitoring, students learn to assume responsibility for 
their understanding and take steps to restore meaning (Carr, et.al, 2004:197).

\section{e. Predicting}

Predicting requires students to recall relevant background knowledge about a topic and form a hypothesis about what the author will discuss in each section of the text. Students then read with a purpose, linking new and prior knowledge as they infer information and refine their predictions (Carr, et.al, 2004:197).

\subsection{Descriptive Text}

The text type which is used in the research was Descriptive Text. Learning descriptive text for students was very important. As cited in English K6- Modules (2001:85), the ability to describe someone or something in detail is an important skill that can contribute to a number of different text types. Wardiman, et.al (2008:16) argued that a descriptive text is a text that describes the features of someone, something, or a certain place. Cited in English K6 Modules (2001:85), descriptions focus our attention on the characteristic features of a particular thing. The subject might be a person, or a thing. It might be impressionistic or imaginative, or an objective description.

Based on the quotation above it can be concluded that descriptive text is a text that describes things or certain thing, such as person, animal, and thing.

a. The Language Features of Descriptive Text

Cited in English K-6 Modules (2001:85), common grammatical patterns of a description include:

b. Use of particular nouns, example:

1) Elephants and tigers

2) The bears and the monkeys

c. Use of detailed noun groups to provide information about the subject, example:

1) Tigers are the biggest of all cats.

2) Tigers stripped coat gives them good camouflage when they hunt.

d. Use of a variety of types of adjectives, example:

1) Describing, for instance: Tigers are intelligent.

2) Numbering, for instance: Most of tigers live in Africa.

3) Classifying, for instance: Monkeys live in groups called troops.

e. Use of relating verbs to provide information about the subject, example:

1) Bears are large and powerful.

2) Monkeys are clever mammals.

f. Use of thinking and feeling verbs to express the writer's personal view about the subject or to give an insight into the subject's thoughts and feelings, example:

1) Bears have a good sense of smell.

2) Tigers love meat to eat.

g. Use of action verbs to describe the subject's behavior Example:

1) Bears use their long trunks almost like an arm, to put food and water inmouths.

2) Monkeys eat plants.

h. Use of adverbials to provide more information about this behavior, example:

1) Elephants live in Africa and Asia.

2) Tigers jump fast. 


\subsection{The Design of the Study}

\section{Methodology}

The study was designed into quantitative method by following pre- experimental of one group pre-test and post-test design. The design of one group pre-test and post-test design is described below:

Table 1. The Design of the Study

\begin{tabular}{|c|c|c|}
\hline $\mathrm{X}_{1}$ & $\mathrm{~T}$ & $\mathrm{X}_{2}$ \\
\hline \multicolumn{3}{|c|}{ Source: Hatch and Lazaraton (1991:87) } \\
\hline
\end{tabular}

Note: $\mathrm{X}_{1}$ : Distributing pre-test to the students

$\mathrm{T}$ : Treatment of Reciprocal Teaching Strategy

$\mathrm{X}_{2}$ : Distributing post-test to the students.

\subsection{The Population and Sample of the Study}

\section{a. The Population of the Study}

Arikunto (2006:130) argued that population is a set or collection of all elements possessing one or more attributes of interest. And, in this research the population of the study was taken from VIII SMP Swasta PTPN IV Bah Jambi with 63 students as tabulated below:

Table 2: Population of the Study

\begin{tabular}{|c|c|c|}
\hline No. & Class & Population \\
\hline 1. & VIII $^{-1}$ & 21 \\
\hline 2. & VIII $^{-2}$ & 21 \\
\hline
\end{tabular}

\section{b. The Sample of the Study}

Arikunto (2006:131) argued that sample is partly or representative of population that will be searched. In this study the writer took the sample of the study by using purposive sampling technique because the school has renovation so that the head minister permitted the writer to take one class as the sample of the research. Due to the condition, the writer used lottery to choose the sample. The lottery consisted of three rolling pieces of paper, where two papers were empty but the third paper contained number one. Each leader of the class fetched one rolling paper and those who of the leaders got the paper contained number one became the sample of the study. Here, the writer found that the leader of class VIII ${ }^{-1}$ got the contained paper so that class $\mathrm{VIII}^{-1}$ was the sample of the study with 21 students.

\subsection{The Technique of Analyzing Data}

To analyze the data, the writer followed some statistical techniques, as following:

a. Scoring the students' multiple choices.

b. Tabulating pre-test scores and post-test scores.

c. Finding frequency and normality of the test by using SPSS Version 16.0 for Windows.

d. Finding the mean of pre-test and post-test by means of formula below: 


$$
\bar{X}=\frac{\sum X}{N}
$$

Note:

$$
\begin{array}{ll}
\bar{X} & : \text { mean } \\
\mathrm{X} & : \text { total score of pre-test } \\
\mathrm{Y} & : \text { total score of post-test } \\
\mathrm{N} & : \text { number of sample (Hatch and Lazaraton, 1991:162) }
\end{array}
$$

e. Finding the Standard Deviation of the test by using formula below:

$$
\mathrm{S}=\frac{1}{\mathrm{~N}} \text { [INK Word. Document. } 12 \text { D: [ RUSMAN BUTAR BUTAR \ENGLISH PROJ] }
$$

Note:

$$
\begin{aligned}
& \mathrm{S}: \text { Standard deviation } \\
& \mathrm{N}: \text { Number of sample } \\
& \sum \mathrm{x}: \text { Total score }
\end{aligned}
$$

f. Finding the standard deviation difference of the test by using formula below:

Note:

$$
S_{D}=\sqrt{\frac{\sum D^{2}-(1+n)\left(\sum D\right)^{2}}{n-1}}
$$

$\mathrm{S}_{\mathrm{D}}:$ Standard difference

D : Difference

$\mathrm{D}^{2}$ : Difference gain pre-test and post-test which is squared

1 : Constant value

N : Number of sample (Hatch and Lazaraton, 1991:289)

g. Finding the standard error difference by using formula below:

Note:

$$
S_{\bar{D}}=\frac{S_{D}}{\sqrt{N}}
$$

$S_{\bar{n}}:$ Standard error difference

$\mathrm{S}_{\mathrm{D}}:$ Standard difference

N : Number of sample (Hatch and Lazaraton, 1991:289)

h. Testing hypothesis by using formula:

Note:

$$
t=\frac{M d}{\sqrt{\frac{\sum X^{2} d}{N(N-1)}}}
$$

Md : Mean difference

$\mathrm{Xd}$ : Difference deviation

df : degree of freedom

$\mathrm{N}$ : Number of samples (Arikunto, 2006:86)

Statistical criterion of determining hypothesis:

a. If $t_{0}>t_{t}$ so, hypothesis alternative (Ha) is accepted and hypothesis null (Ho) is rejected. It showed that the use of Reciprocal teaching strategy gives significant 
improvement on students' achievement in reading descriptive text at grade VIII SMP Swasta PTPN IV Bah Jambi in academic year 2018/2019.

b. If $t_{o}<t_{t}$ so, hypothesis null (Ho) is accepted and hypothesis alternative (Ha) is rejected. It showed that the use of Reciprocal teaching strategy does not give significant improvement on students' achievement in reading descriptive text at grade VIII SMP Swasta PTPN IV Bah Jambi in academic year 2018/2019.

c. The degree of freedom (df) was $\mathrm{df}=\mathrm{N}-1=21-1=25$. Then, the critic value for $\mathrm{t}_{\text {table }}$ was compared with $\mathrm{t}_{\text {table }} \%=2,086$ and $\mathrm{t}_{\text {table } 1 \%}=2,845$.

\section{Data Analysis and Interpretation}

\subsection{Data Analysis}

Data of the study concerned on Improving Students' Achievement in Reading Descriptive Text through Reciprocal Teaching Strategy. The study was conducted at grade VIII SMP Swasta PTPN IV Bah Jambi in academic year 2018/2019.

The data of the study consisted on pre-test data and post-test data. The pre- test data were distributed before the treatment of Reciprocal Teaching Strategy and the post-test data were taken after the treatment of teaching-learning reading descriptive text by using Reciprocal Teaching Strategy.

The data analysis was conducted to know the use of Reciprocal Teaching Strategy on students' achievement in reading descriptive text at grade VIII SMP Swasta PTPN IV Bah Jambi in academic year 2018/2019. So, the data analysis was started by scoring the students' multiple choices, tabulating pre-test scores and post-test scores, finding frequency and normality of the test by using SPSS Version 6.0 for Windows, finding the mean of pre-test and post-test, finding the standard deviation of the test, finding the standard deviation difference of the test, finding the standard error difference, finding mean difference, finding standard error mean difference, and then testing hypothesis. The data analysis was presented as following:

\section{a. The Pre-Test Data}

To know the prior knowledge of the students in reading descriptive text, the writer distributed pre-test at the begiinning was tabulated as follows,

Table 3 The Pre-test Data (X)

\begin{tabular}{|l|l|l|l|}
\hline No. & Students & $\mathrm{X}$ & $\mathrm{X}^{2}$ \\
\hline 1. & Sukama P. & 20 & 400 \\
\hline 2. & Fika & 20 & 400 \\
\hline 3. & Zihan N. & 35 & 1225 \\
\hline 4. & M. Vio A. & 30 & 900 \\
\hline 5. & M. Dimas A. & 55 & 3025 \\
\hline 6. & Angga R.S. & 40 & 1600 \\
\hline 7. & Umi S. & 15 & 225 \\
\hline
\end{tabular}




\begin{tabular}{|l|l|l|l|}
\hline 8. & Deva Ade S. & 25 & 625 \\
\hline 9. & Dzaki F.B. & 25 & 625 \\
\hline 10. & Nicho A. & 20 & 400 \\
\hline 11. & Adrian A.W. & 20 & 400 \\
\hline 12. & Zahra F. & 50 & 2500 \\
\hline 13. & Ayu M.P. & 45 & 2025 \\
\hline 14. & Widya N. & 30 & 900 \\
\hline 15. & Kumala D.S. & 35 & 1225 \\
\hline 16. & M. Al-Buchari & 10 & 100 \\
\hline 17. & Rima H. & 10 & 100 \\
\hline 18. & Malik W.Y. & 15 & 225 \\
\hline 19. & Habib J.S. & 10 & 100 \\
\hline 20. & Nurul N. & 15 & 225 \\
\hline 21. & Nila & 20 & 400 \\
\hline$\sum$ & & 545 & 17625 \\
\hline
\end{tabular}

Based on the table above, it was found that from the number of sample 21, the total score of the pre-test was 545 .

\section{1) The Frequency of the Test}

The frequency of pre-test data was calculated to know how often points existed in the pre-test data. The calculation was conducted by using SPSS Version 16.0 for Windows, as following:

Table 4. Pre-test Data

\begin{tabular}{|c|c|c|c|}
\hline $\mathrm{X}$ & $\mathrm{F}$ & Percent & Valid Percent \\
\hline 10 & 3 & 14.3 & 14.3 \\
\hline 15 & 3 & 14.3 & 14.3 \\
\hline 20 & 5 & 23.8 & 23.8 \\
\hline 25 & 2 & 9.5 & 9.5 \\
\hline 30 & 2 & 9.5 & 9.5 \\
\hline 35 & 2 & 9.5 & 9.5 \\
\hline 40 & 1 & 4.8 & 4.8 \\
\hline 45 & 1 & 4.8 & 4.8 \\
\hline 50 & 1 & 4.8 & 4.8 \\
\hline 55 & 1 & 4.8 & 4.8 \\
\hline Total & 21 & 100.0 & 100.0 \\
\hline
\end{tabular}


Based on the table above, it was found that before the treatment of Reciprocal Reading Strategy, the lowest score was 10 and the highest score was 55 from 20 items of multiple choices.

\section{2) The Normality of the Test}

The normality of the pre-test data was calculated to measure whether the distribution of the data is normal or not. Based on the calculation used by SPSS Version 16.0 for Windows, the normality of the pre-test data was tabulated at the following table:

Table 5. Normality of the Pre-test Data

\begin{tabular}{|c|c|c|c|c|c|c|}
\hline \multirow{4}{*}{ Pre-test } & \multicolumn{3}{|c|}{ Kolmogorov-Smirnov $^{\mathrm{a}}$} & \multicolumn{3}{c|}{ Shapiro-Wilk } \\
\cline { 2 - 7 } & Statistic & $\mathrm{df}$ & Sig. & Statistic & $\mathrm{df}$ & Sig. \\
\cline { 2 - 7 } & .198 & 21 & .031 & .917 & 21 & .075 \\
\hline
\end{tabular}

The interpretation of the normality was compared with Shapiro-Wilk by means of criterions below:

a. If $\operatorname{sig}>\alpha(0,05)$, the pre-test data is called normal distributed.

b. If sig $<\alpha(0,05)$, the pre-test data is called not normally distributed.

Based on table above it was found that $\operatorname{Sig}>\alpha(0,075>0,05)$ so that the pre-test data is normally distributed.

\section{3).The Mean of the Test}

Mean pre-test was calculated to know the students' basic knowledge in reading descriptive text before the treatment of Reciprocal Reading Strategy. So, the mean of the pretest data was:

$$
\begin{gathered}
\bar{X}=\frac{\sum X}{N} \\
\bar{X}=\frac{545}{21} \\
\bar{X}=25,95
\end{gathered}
$$

Based on the calculation above it was found that before the treatment of Reciprocal Reading Strategy, the students' achievement in reading descriptive text was low since the mean of the pre-test data was 25,95 .

\section{4) The Standard Deviation of the Test}

The standard deviation of pre-test data was calculated to determine how the data is distributed in a sample and how close an individual data point to the mean or average sample value. So, it was calculated as following:

$\mathrm{S}=\frac{1}{\mathrm{~N}} \Xi$ LINK Word. Document. 12 D $\backslash \backslash$ RUSMAN BUTAR BUTAR $\backslash \backslash$ ENGLISH PROJECT 20 
$\mathrm{S}=\frac{1}{21} \mathbb{1}$ LINK Word. Document. 12 D: $\backslash \backslash$ RUSMAN BUTAR BUTAR $\backslash \backslash$ ENGLISH PROJECT 2

$$
\begin{aligned}
& S=\frac{1}{21}, 270,37 \\
& S=1270, \frac{37}{21}
\end{aligned}
$$

$\mathrm{S}=13.193$

Based on the calculation above it was found that the standard deviation of pre-test data was 13,193. So, the histogram of the pre-test was:

\section{Diagram 1 Histogram of Pre-test Data}

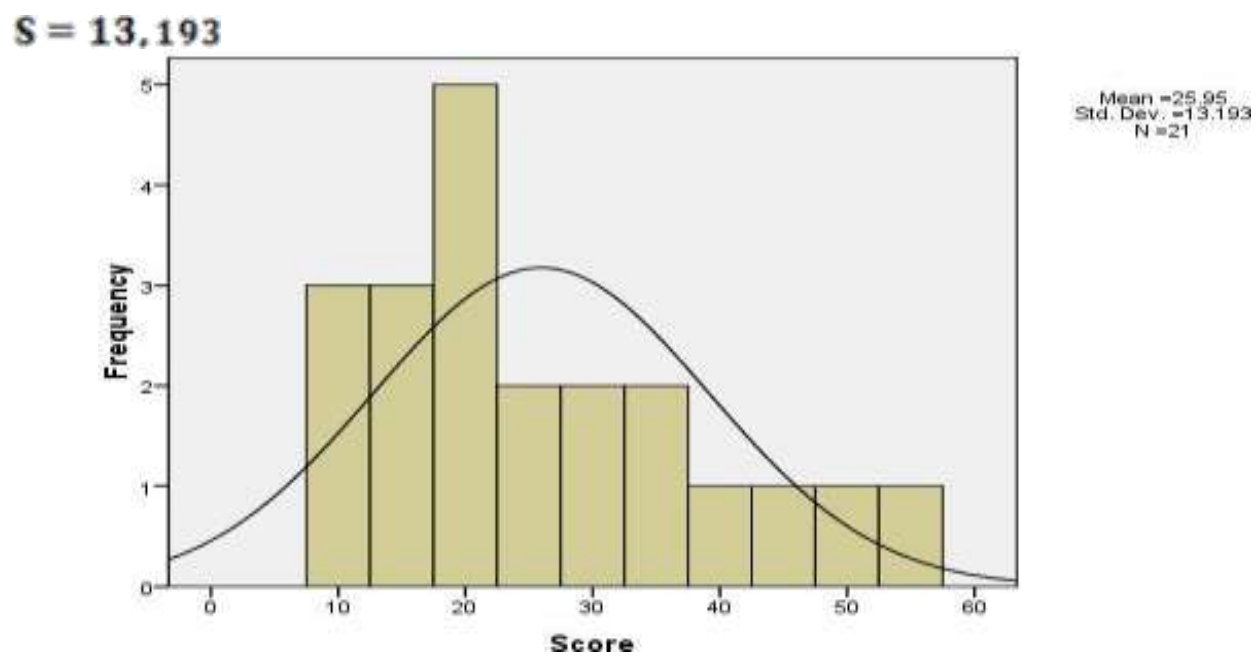

Based on the diagram 4.1 above, it was found that the number of the students were 21 students and the mean was 25,95 while the standard deviation was 13,193 . Then, students who got score 10 consisted of $3(14,3 \%)$ students and students who got score 15 were 3 $(14,3 \%)$ students. Students who got score 20 consisted of $5(23,8 \%)$ students and students who got score 25 were $2(9,5 \%)$ students. Students who got score 30 consisted of $2(9,5 \%)$ students and students who got score 35 were $2(9,5 \%)$ students. There was $1(4,8 \%)$ student who got score 40 and who got score 45 consisted of 1 (4,8\%). Then, student who got score 50 consisted of $1(4,8 \%)$ student, while student who got score 55 was $1(4,8 \%)$ student.

\subsection{The Post-test Data}

Post-test data was calculated to know the students' improvement in reading descriptive text after the treatment of Reciprocal Reading Strategy and the post-test data was tabulated as follows: 
Table 6. The Post-test Data (Y)

\begin{tabular}{|l|l|c|c|}
\hline No. & Students & $\mathrm{Y}$ & $\mathrm{Y}^{2}$ \\
\hline 1. & Sukama P. & 70 & 4900 \\
\hline 2. & Fika & 80 & 6400 \\
\hline 3. & Zihan N. & 65 & 4225 \\
\hline 4. & M. Vio A. & 75 & 4225 \\
\hline 5. & M. Dimas A. & 80 & 5625 \\
\hline 6. & Angga R.S. & 75 & 6400 \\
\hline 7. & Umi S. & 55 & 5625 \\
\hline 8. & Deva Ade S. & 65 & 4225 \\
\hline 9. & Dzaki F.B. & 70 & 4900 \\
\hline 10. & Nicho A. & 70 & 4900 \\
\hline 11. & Adrian A.W. & 75 & 5625 \\
\hline 12. & Zahra F. & 70 & 4900 \\
\hline 13. & Ayu M.P. & 70 & 4900 \\
\hline 14. & Widya N. & 70 & 4900 \\
\hline 15. & Kumala D.S. & 65 & 4225 \\
\hline 16. & M. Al-Buchari & 75 & 5625 \\
\hline 17. & Rima H. & 65 & 6400 \\
\hline 18. & Malik W.Y. & 4225 \\
\hline 19. & Habib J.S. & Nurul N. & 3600 \\
\hline 20. & Nila & 4225 \\
\hline 21. & \multicolumn{1}{|c|}{$\sum$} & 103075 \\
\hline
\end{tabular}

Based on the table above, it was found that from the number of sample 21, the total score of the post-test was 1465 .

\section{1) The Frequency of the Test}

The frequency of post-test data was calculated to know how often points existed in the post-test data. The calculation was also conducted by using SPSS Version 16.0 for Windows, as following: 
Table 7. Frequency of Post-test Data

\begin{tabular}{|c|c|c|c|}
\hline $\mathbf{X}$ & F & Percent & Valid Percent \\
\hline 55 & 1 & 4.8 & 4.8 \\
\hline 60 & 1 & 4.8 & 4.8 \\
\hline 65 & 6 & 28.6 & 28.6 \\
\hline 70 & 6 & 28.6 & 28.6 \\
\hline 75 & 4 & 19.0 & 19.0 \\
\hline 80 & 3 & 14.3 & 14.3 \\
\hline Total & 21 & 100.0 & 100.0 \\
\hline
\end{tabular}

Based on the table 7 above, it was found that after the treatment of Reciprocal Reading Strategy, the lowest score was 55 and the highest score was 80 from 20 items of multiple choices.

\section{2) The Normality of the Test}

The normality of the post-test data was also calculated to measure whether the distribution of the data is normal or not. So, the normality of the post-test data was tabulated at the following table:

Table 8. Normality of the Post-test Data

\begin{tabular}{|l|c|c|c|c|c|c|}
\hline Post-test & \multicolumn{3}{|c|}{ Kolmogorov-Smirnov ${ }^{\mathrm{a}}$} & \multicolumn{3}{c|}{ Shapiro-Wilk } \\
\cline { 2 - 7 } & Statistic & $\mathrm{df}$ & Sig. & Statistic & $\mathrm{df}$ & Sig. \\
\hline & 0,152 & 21 & $0,200^{*}$ & 0,935 & 21 & 0,177 \\
\hline
\end{tabular}

The interpretation of the normality was also compared with Shapiro-Wilk by means of criterions below:

- If $\operatorname{sig}>\alpha(0,05)$, the post-test data is called normal distributed.

- If $\operatorname{sig}<\alpha(0,05)$, the post-test data is called not normally distributed.

Based on table 4.6 above it was found that $\operatorname{Sig}>\alpha(0,177>0,05)$ so that the posttest data is normally distributed.

\section{3) The Mean of the Test}

Mean post-test was also calculated to know the students' improvement on the students' achievement in reading descriptive text after the treatment of Reciprocal Reading Strategy. So, the mean of the post-test data was:

$$
\begin{aligned}
& \bar{X}=\frac{\sum Y}{N} \\
& \bar{X}=\frac{1465}{21} \\
& \bar{X}=69,76
\end{aligned}
$$


Based on the calculation above it was found that after the treatment of Reciprocal Reading Strategy, the students' achievement in reading descriptive text was good since the mean of the post-test data was 69,76 .

\section{4).The Standard Deviation of the Test}

The standard deviation of post-test data was also calculated to determine how the data is distributed in a sample and how close an individual data point to the mean or average sample value. So, the standard deviation of post-test data was calculated as following $S=\frac{1}{N}$ DINK Word. Document. 12 D: $\backslash \backslash$ RUSMAN BUTAR BUTAR $\backslash \backslash$ ENGLISH PROJECT 20

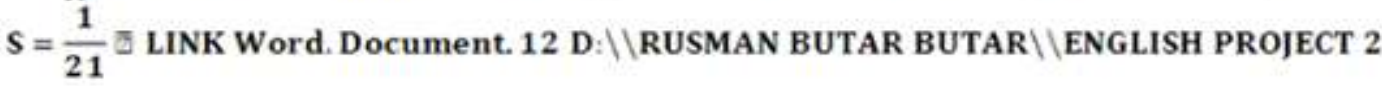

Diagram 2. Histogram of Pre-test Data

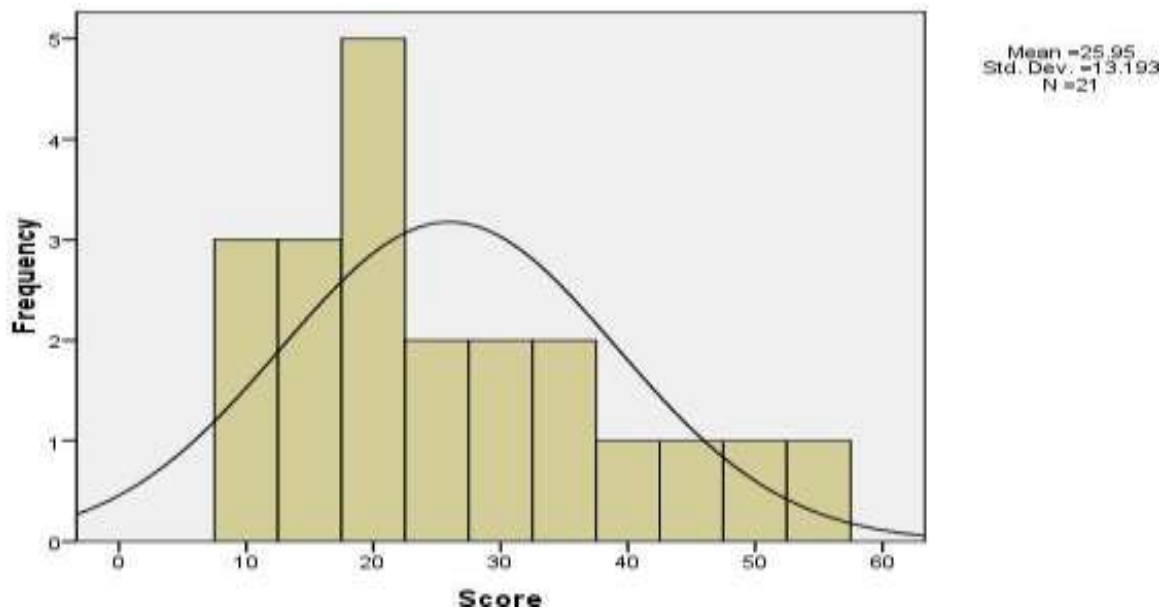

Based on the diagram 4.1 above, it was found that the number of the students were 21 students and the mean was 25,95 while the standard deviation was 13,193 . Then, students who got score 10 consisted of $3(14,3 \%)$ students and students who got score 15 were 3 $(14,3 \%)$ students. Students who got score 20 consisted of $5(23,8 \%)$ students and students who got score 25 were $2(9,5 \%)$ students. Students who got score 30 consisted of $2(9,5 \%)$ students and students who got score 35 were $2(9,5 \%)$ students. There was $1(4,8 \%)$ student who got score 40 and who got score 45 consisted of 1 (4,8\%). Then, student who got score 50 consisted of $1(4,8 \%)$ student, while student who got score 55 was $1(4,8 \%)$ student.

\subsection{The Standard Deviation Difference}

The standard deviation difference was calculated to know how much difference variability there were in pre-test data and post-test data. So, the calculation was:

Table 4. Gain Scores Before and After Treatment

\begin{tabular}{|l|l|c|c|c|c|c|c|}
\hline No. & \multicolumn{1}{|c|}{ Students } & X & Y & \multicolumn{1}{c|}{$\mathbf{D}$} & \multicolumn{1}{c|}{$\mathbf{D}^{\mathbf{2}}$} & \multicolumn{1}{c|}{$\mathbf{X}_{\mathbf{d}}$} & \multicolumn{1}{c|}{$\mathbf{X}^{\mathbf{2}} \mathbf{~}$} \\
\hline 1. & Sukama P. & 20 & 70 & 50 & 2500 & 6,19 & 38,32 \\
\hline 2. & Fika & 20 & 80 & 60 & 3600 & 16,19 & 262,12 \\
\hline 3. & Zihan N. & 35 & 65 & 30 & 900 & $-13,81$ & 190,72 \\
\hline 4. & M. Vio A. & 30 & 65 & 35 & 1225 & $-8,81$ & 77,62 \\
\hline
\end{tabular}




\begin{tabular}{|l|l|l|l|l|l|l|l|}
\hline 5. & M. Dimas A. & 55 & 75 & 20 & 400 & $-23,81$ & 566,92 \\
\hline 6. & Angga R.S. & 40 & 80 & 40 & 1600 & $-3,81$ & 14,52 \\
\hline 7. & Umi S. & 15 & 75 & 60 & 3600 & 16,19 & 262,12 \\
\hline 8. & Deva Ade S. & 25 & 55 & 30 & 900 & $-13,81$ & 190,72 \\
\hline 9. & Dzaki F.B. & 25 & 65 & 40 & 1600 & $-3,81$ & 14,52 \\
\hline 10. & Nicho A. & 20 & 70 & 50 & 2500 & 6,19 & 38,32 \\
\hline 11. & Adrian A.W. & 20 & 70 & 50 & 2500 & 6,19 & 38,32 \\
\hline 12. & Zahra F. & 50 & 75 & 25 & 625 & $-18,81$ & 353,82 \\
\hline 13. & Ayu M.P. & 45 & 70 & 25 & 625 & $-18,81$ & 353,82 \\
\hline 14. & Widya N. & 30 & 70 & 40 & 1600 & $-3,81$ & 14,52 \\
\hline 15. & Kumala D.S. & 35 & 70 & 35 & 1225 & $-8,81$ & 77,62 \\
\hline 16. & M. Al-Buchari & 10 & 65 & 55 & 3025 & 11,19 & 125,22 \\
\hline 17. & Rima H. & 10 & 75 & 65 & 4225 & 21,19 & 449,02 \\
\hline 18. & Malik W.Y. & 15 & 80 & 65 & 4225 & 21,19 & 449,02 \\
\hline 19. & Habib J.S. & 10 & 65 & 55 & 3025 & 11,19 & 125,22 \\
\hline 20. & Nurul N. & 15 & 60 & 45 & 2025 & 1,19 & 1,42 \\
\hline 21. & Nila & 20 & 65 & 45 & 2025 & 1,19 & 1,42 \\
\hline$\sum$ & & $\mathbf{5 4 5}$ & $\mathbf{1 4 6 5}$ & $\mathbf{9 2 0}$ & $\mathbf{4 3 9 5 0}$ & $\mathbf{- 0 , 0 1}$ & $\mathbf{3 6 4 5 , 2 4}$ \\
\hline
\end{tabular}

Based on table above it was found that: X 545

$\begin{array}{ll}\mathrm{Y} & 1465 \\ \mathrm{D} & 920 \\ \mathrm{D}^{2} & 43950 \\ \mathrm{X}_{\mathrm{d}} & :-0,01 \\ \mathrm{Xd}^{2} & : 3645,24\end{array}$

So, the standard deviation difference was:

$$
\begin{aligned}
& S_{D}=\sqrt{\frac{\sum D^{2}-(1+n)\left(\sum D\right)^{2}}{n-1}} \\
& S_{D}=\sqrt{\frac{43950-(1+21)(920)^{2}}{21-1}} \\
& S_{D}=\sqrt{\frac{43950-(0,0476190476)(846400)}{20}} \\
& S_{D}=\sqrt{182,26} \\
& S_{D}=13,50
\end{aligned}
$$

Based on the calculation above, it was found that the standard deviation difference before and after the treatment of Reciprocal Reading Strategy was 13,50.

\subsection{The Standard Error Difference}

The standard error difference was calculated to show how much difference variability there are in scores. So, the standard error difference between the pre- test data and the posttest data was calculated as following: 


$$
\begin{aligned}
& S_{\bar{D}}=\frac{S_{D}}{\sqrt{N}} \\
& S_{\bar{D}}=\frac{13,50}{\sqrt{N}} \\
& S_{\bar{D}}=\frac{13,50}{\sqrt{21}} \\
& S_{\bar{D}}=2,95
\end{aligned}
$$

Based on the calculation above, it was found that the standard error difference between pre-test data and post-test data was 2,95 .

\subsection{The Mean Difference}

Mean difference was calculated to know the improvement of the students before and after the treatment based on the mean. So, the mean difference was calculated as following:

$$
\begin{aligned}
& M_{D}=\frac{\sum D}{N} \\
& M_{D}=\frac{920}{21} \\
& M_{D}=43,81
\end{aligned}
$$

Based on the calculation above, it was found that mean difference before and after the treatment of Reciprocal Reading Strategy was 43,81.

\subsection{The Standard Error Mean Difference}

The Standard Error Mean Difference was calculated to know the probability of error calculation of the mean difference between pre-test and post- test data. So, the calculation was as following:

$$
\begin{aligned}
& S E_{M D}=\frac{S D_{D}}{\sqrt{N-1}} \\
& S E_{M D}=\frac{2,95}{\sqrt{21-1}} \\
& S E_{M D}=\frac{2,95}{\sqrt{20}} \\
& S E_{M D}=\frac{2,95}{4,47} \\
& S E_{M D}=0,66 .
\end{aligned}
$$

Based on the calculation above, it was found that the standard error mean difference before and after the treatment was 0,66.

\subsection{Testing Hypothesis}

$$
S E_{M D}=0,66
$$

Testing hypothesis was conducted to know whether use of Reciprocal teaching strategy gives significant improvement on students' achievement in reading descriptive text 
at grade VIII SMP Swasta PTPN IV Bah Jambi or not. The testing hypothesis was as following

$$
\begin{aligned}
& t=\frac{43,81}{\sqrt{\frac{3645,24}{21(20)}}} \\
& t=\frac{43,81}{\sqrt{\frac{3645,24}{420}}} \\
& t=\frac{M d}{\sqrt{\frac{\sum X^{2} d}{N(N-1)}}} \\
& t=\frac{43,81}{\sqrt{\frac{3645,24}{21(21-1)}}}
\end{aligned}
$$

Based on the calculation above, it was found that tobservation was 14,851 . So, to determine which hypothesis is accepted and rejected, the following hypotheses statistical are followed:

a. If $t_{0}>t_{t}$ so, hypothesis alternative (Ha) is accepted and hypothesis null (Ho) is rejected. It showed that the use of Reciprocal teaching strategy gives significant improvement on students' achievement in reading descriptive text at grade VIII SMP Swasta PTPN IV Bah Jambi.

b. If $t_{o}<t_{t}$ so, hypothesis null (Ho) is accepted and hypothesis alternative (Ha) is rejected. It showed that the use of Reciprocal teaching strategy does not give significant improvement on students' achievement in reading descriptive text at grade VIII SMP Swasta PTPN IV Bah Jambi.

c. The degree of freedom (df) was $\mathrm{df}=\mathrm{N}-1=21-1=25$. Then, the critic value for table was compared with table $5 \%=2,086$ and table $1 \%=2,845$.

Based on the hypotheses statistical above, it was found that $t_{\text {table }} \%<t_{\text {observation }}>t_{\text {table }}$ $1 \%(2,086<14,851>2,845)$. So, Hypothesis alternative $(\mathrm{Ha})$ was accepted and Hypothesis null (Ho) was rejected. It means that the use of Reciprocal teaching strategy gives significant improvement on students' achievement in reading descriptive text at grade VIII SMP Swasta PTPN IV Bah Jambi in academic year 2018/2019.

\subsection{The Finding of the Study}

After analyzing the data, the writer found some findings of the study; they are as following:

1. Before the treatment of Reciprocal Reading Strategy, the students' achievement in reading descriptive text was low, where the total score of pre-test data was 545 and the mean was 25,95 .

2. After the treatment of Reciprocal Reading Strategy, the improvement of the students' achievement in reading descriptive text was good where the total score of post-test data was 1465 and the mean was 69,76 .

3. From the frequency of the test, it was found that in pre-test data the lowest score 
was 10 and the highest score was 55 and in the post-test data, the lowest score was 55 and the highest score was 80 .

4. From the normality of the test, it was found that in pre-test data $\operatorname{Sig}>\alpha(0,075>0$, $05)$ and in post-test data it was found that $\operatorname{Sig}>\alpha(0,177>0,05)$ so that the instrument of the study was normally distributed.

5. The standard deviations of pre-test and post-test data were 13,193 and 6,610.

6. The value of standard deviation difference both of the tests was 13,50

7. The value of standard error difference both of the tests was 2,95.

8. The mean difference before and after the treatment of Reciprocal Reading Strategy was 43,81 .

9. The value of Standard Error Mean Difference was 0,66.

10. Based on the testing hypothesis it was found that table $5 \%<$ tobservation $>$ table $1 \%$ $(2,086<14,851>2,845)$. So, Hypothesis alternative (Ha) was accepted and Hypothesis null (Ho) was rejected. It means that the use of Reciprocal teaching strategy gives significant improvement on students' achievement in reading descriptive text at grade VIII SMP Swasta PTPN IV Bah Jambi in academic year 2018/2019

\section{Conclusion}

Based on the data analysis and the findings of the study, this study was concluded that before the treatment of Reciprocal Reading Strategy, the basic knowledge of students at grade VIII SMP Swasta PTPN IV Bah Jambi was low since the mean of pre-test data was 25,95 and after the treatment, the students' achievement in reading descriptive text was good where the mean of post-test data was 69,76 so that the mean difference before and after the treatment was 43,81 . Besides that, the instrument of the study was normally distributed. Finally, from the testing hypothesis it was found that $t_{\text {table }} \%<t_{\text {observation }}>t_{\text {table }} 1 \%(2,086<14,851>2,845)$.

So, Hypothesis alternative (Ha) was accepted and Hypothesis null (Ho) was rejected. It means that the use of Reciprocal teaching strategy gives significant improvement on students' achievement in reading descriptive text at grade VIII SMP Swasta PTPN IV Bah Jambi in academic year 2018/2019.

\section{References}

Arikunto, Suharsimi. 2006. Prosedur Penelitian: Suatu Pendekatan Praktik. Jakarta: PT Rineka Cipta Carr, Eileen, et.al. 2004. Teaching Comprehension: A Systematic and Practical Framework with Lessons and Strategies. New York: Thinking Works

Dakowska, Maria. 2005. Teaching English as a Foreign Language: A Guide for a Professional. Warszawa: Wydawnictwo Naukowe PWN SA

El-Koumy, A.S. 2016. Teaching English as a Foreign Language to Students with Learning Disabilities at the Intermediate and Advanced Levels: A Multiple-Strategies Approach. Egypt: Suez University

English K-6 Modules. 2001. English K-6 Modules. Sydney: Board of Studies NSW

Frank, Cecilia, B, et.al. 2006. Applications of Reading Strategies within the Classroom: Explanations, Models, and Teacher Templates for Content Areas in Grade 3-12. Boston: Pearson

Hatch, Evelyn and Lazaraton, Anne. 1991. The Research Manual: Design and Statistics for 
Applied Linguistics. Massachusetts: Heinle \& Heinle Publisher

Klingner, Janette K. et.al. 2007. Teaching Reading Comprehension to Students with Learning Difficulties. New York: The Guilford Press

Nunan, David. 2003. Practical English Language Teaching: First Edition. New York: McGraw-Hill Companies, Inc

Pang. S. Elizabeth, et.al. 2003. Teaching Reading: The International Academy of Education (IAE), International Bureau of Education (IBE) UNESCO. Brussels: IAE, IBE and UNESCO

Scanlon, Donna M, et.al. 2010. Early Intervention for Reading Difficulties: The Interactive Strategies Approach. New York: The Guilford Press

Sudijono, Anas. 2007. Pengantar Statistik Pendidikan. Jakarta: PT Raja Grafindo Persada

Vassiliou, A. 2011. Teaching Reading in Europe: Contexts, Policies and Practices. Brussels: Avenue du Bourget 1 (BOU2)

Wachidah, Siti, et.al. 2017. Bahasa Inggris When English Rings a Bell. Jakarta: Pusat Kurikulum dan Perbukuan, Balitbang, Kemendikbud

Wardiman, Artono, et all. 2008. English in Focus: for Grade VII Junior High School (SMP/MTS) Pendidikan Nasional, Pusat Perbukuan Department.

Westwood, Peter. 2008. What Teachers Need to Know About Reading and Writing Difficulties. Victoria: Acer Press 